\title{
Effective Employment of Presentation in Business Japanese Teaching
}

\author{
$\mathrm{Xu}$ Kun \\ Japanese Department, Dalian Neusoft University of information \\ Liao Ning
}

\begin{abstract}
The paper analyzes the problems of presentations in business Japanese teaching, discussing how to guide students to presentation and cultivate students' autonomous learning ability better, in order to make better use of presentations. The presentation conducted by students and guided by teachers is a practical teaching model. Meanwhile, this paper illustrates briefly how to use self-assessment and mutual assessment in presentations.
\end{abstract}

Keywords—-presentation; class teaching; students' subjectivity; self and mutual assessment

\section{INTRODUCTION}

Currently, business Japanese teaching emphasizes that teachers should focus on the student's subjectivity and helping them achieve "learning in practicing" [1]. The traditional class teaching model is basically teacher-dominated. Teachers teach knowledge to students and students have been accustomed to this way of learning in which they listen to the teacher carefully sitting. This kind of class is boring and it is hard for students to be active and get involved in that they are distracted easily. The teachers have to spend time maintain the order and then cannot finish their teaching task. That is the reason why it is one of the issues of common concern that how to change the role of students, increase their subjectivity and place them in business Japanese scene.

Presentation is a common method of business Japanese teaching and has been adopted by many teachers, due to its flexibility and diversity [2]. It is a kind of class where students are the center. A group of students make a business situational dialogue or make a presentation about a specific topic, then interact with the audience. Having made students master what they learn, teachers organize students come to the platform and play roles, applying the Japanese they have learned in a more relaxing atmosphere. Presentation make students understand language better and give them opportunities to communicate in Japanese in a relatively real situation, which make it less a shortcoming that students are not in a Japanese environment. In Japanese teaching, beginners make simple dialogue, because their limited ability to express and seniors present on a certain topic [3].

The advantages of presentations are as follows:
- Enriching students' knowledge in business Japanese;

- improving their self-learning ability;

- enhancing confidence; improving the ability in using spoken Japanese;

- Stimulating interests in learning; making the class more alive.

- A presentation for a group can even cultivate students' team spirits.

Thus presentation is an effective way to improve students' spoken Japanese, self-learning ability and team spirits. It can also intensify the subjectivity of students.

\section{THE PROBLEMS IN CURRENT PRESENTATIONS}

There is no doubt about the role of presentation. In reality, however, many teachers complain that presentation has become a mere form which not only does not work, but waste time. It does not achieve the desired effect [4].

From the teachers' point of view, the problems are as follows:

1) Students who are to present are not well-prepared. Their dialogues are illogical, full of grammar mistakes. Students lack knowledge in business etiquettes. A few of them present with a script at hand and cannot be fully understood. In basic business Japanese teaching, presentation is a group task in which students make dialogue with each other. If one of them has not prepared well and cannot present free of script, the whole team will be affected, thus prolonging their presentation. A few students do not know much about the business etiquettes in Japan. For example: in business meetings, the people of our own team should be introduced to the customers first before we introduce our colleges to the customers. When exchanging business cards, it is after we have confirmed customers' names that we can put the cards 
into pockets. These etiquettes are of great importance in presentations.

2) Although some students have prepared their presentations, they are too nervous and their speeches are too incoherent to be understood. When learning Japanese, business Japanese particularly, students need to talk more, practice more and promote their expression ability through presentation. In these kinds of teaching practices, students become the host of class and speak Japanese in business Japanese situation, thus improving their autonomous learning ability and removing nervousness.

3) Some students use too much written language in their presentation which lack creativity, making it hard for audience to comprehend. In business Japanese presentations, in order to prepare less, students use what is in the textbook directly, which does not even match the theme of their presentation. Honorific Japanese is needed. But honorific Japanese falls into many kinds and there are great differences between written Japanese and spoken Japanese. The teachers should instruct students how to use them flexibly.

4) In presentations, the audiences are absent-minded. Some take it as an opportunity to relax. Some are busy with their own presentations and do not listen to the presenters, causing chaos in class and influencing the teaching results. It is a task for teachers to get all the students involved in the presentations, both the presenters and the audience.

5) When asking questions, the audiences are unable to express themselves clearly that the presenters do not know how to answer them. Interaction happens only among a few people, while most of them keep silent. The presentations for advanced learners are often a report on a special topic by group. They present on a certain topic using PPT. After that, presenters interact with the audience. However, due to students' poor ability of speaking English, the answers are irrelevant to the question or the presenters cannot understand the questions at all, causing awkward moment.

From the student's view, complaints are as follow. Firstly, many topics are derived from textbook. They are old-fashioned so that they cannot help students to use the language they have learned. Secondly, what they have learned in textbook cannot be applied effectively into presentations, owing to their poor ability to use knowledge. Some presentations take too long. During the interaction, either digressions happen sometimes or it takes too much time that it influences teacher's lecturing on textbook. And not all the content in presentation is correct. Little applications of new knowledge make the audience think there is almost nothing to learn. What is more, students do not know much about business etiquettes, thus common-sense mistakes occur often.

\section{THE ROLE OF TEACHERS IN PRESENTATIONS}

Cultivating students' subjectivity is never achieved overnight. We see students' subjectivity in their relations with the teachers. However, teachers forget their roles [5].
What a teacher should do is not letting students come inside the house directly but giving them the key to the door. [6] Once they get the key, they can open the door by themselves. They need to think actively to solve the problem. In terms of intellectual education, it is more important to teach students to grasp the skill of learning or how to learn on their own than to teach them certain knowledge.

In order to raise students' awareness of their subjectivity, what a teacher can do is following.

- Analyzing students' need and help them know their objective.

- Developing students' interests and inspiring their desire to learn.

- Pointing out a right direction for students.

- Guiding students to take advantage of teaching resources and instructing them how to use.

- Acting as an organizer and supervisor.

Aiming at tackling the problems in presentations, I think it is necessary to re-recognize what part a teacher should play.

\section{A. Making guidance instructions for presentations}

When assigning presentations, in addition to explaining the rules and topics, teachers should also emphasize that the goal of presenting is improving their abilities to collect information, communicate orally and cultivating their team spirits. Making students realize the significance can help encourage them to participate. Meanwhile, teachers should teach them basic business terms and etiquettes in case students make mistakes even in the opening remarks. Spending some time teaching students commonly-used sentence patterns and vocabulary before they make presentations can yield twice the result with half the efforts. Under the guidance of teachers, students will gradually dominate the class and learn in a positive environment, thus learning while doing instead of being forced to learn.

Practice is significant in business Japanese teaching. The instructors should tell students the significance and importance of practicing to make them pay attention to and participate in their presentations. To achieve better teaching results, one suggestion would be increase the score of presentation in the curriculum evaluation system, thus forcing students attach enough importance.

\section{B. Guiding students to design their presentations reasonably}

For the beginners' presentation, teacher could help them to revise their script. If possible, teachers can supervise their presentations, correcting some defects and help them adjust the length of presenting. Especially for those poor at oral Japanese, teachers can encourage them to practice repeatedly to relieve their anxiety and familiarize them with their speech. In this way, students can participate actively. 
While for advanced learners, they choose one from some given topics. It is no ground for blame that teachers give certain topics to them, which can stimulate their interests. However, students' language proficiency or knowledge vary, some students select a subject which is too hard for him, some do not consider their subject carefully and have no idea what to present, so they are confused even themselves in front of classmates. These situations all result in failures. Therefore, teachers can check in advance if their topics are proper or not. If it is improper, teachers can discuss something interesting and proper with him. Besides, teachers can suggest some topics based on the textbook in case that their subjects are too different from each other's. In this way, teachers can not only solve the problem that students have difficulties in choosing a topic, but also connect their presentation with textbook.

\section{Offering resources for students' presentations}

Japanese learning resources abound on the Internet in modern days. In addition to some traditional resources such as library and reference books, students can search online, for instance, in Japanese Yahoo, Hujiang website of Japanese and some relevant videos and learning App etc. but at the very beginning, students do not know language well and have problems in collecting information. That is why some students find sentences directly from the textbook and recite them in presentations. Hence teachers can provide resources related to their selected subjects beforehand, including books and websites. It can not only enrich their presentations, but instruct them how to search information. For advanced learners' presentations, the requirements should be higher. They need to present employing PPT, which asks them to gather information. The students should not only prepare their scripts, but make novel and exquisite PPT. In the presentations, they can promote their skills to summarize and expand their Japanese knowledge.

\section{Giving students instruction during their preparations.}

After students finish their script, teachers need to check and correct some errors to make sure students use idiomatic expressions, which also makes the presentation more credible. Presenters can be more confident and the audiences are more willing to listen.

In addition, one of the goals is to improve students' oral Japanese, so teachers can correct their pronunciation and encourage them, because they cannot present themselves well with anxiety. In this way, knowledge can be understood and students can be vitalized. Teachers can raise students' awareness of participation, motivate their enthusiasm and improve their efficiency [7].

What is more, when preparing presentations, students should know what to say as well as being aware of relevant business etiquettes in business situation. Teachers can introduce some video or show them in person the etiquettes while instructing. They should help students understand the importance of business etiquettes and experience them in presenting.

\section{E. Controlling the pace of presentations in class}

Teachers can limit the time properly and tell students the maximum length of time. During presentation, teachers can remind students if they have already run out of time and take the time controlling into evaluation, where insufficient time or excessive time will result in drops of scores. Furthermore, two things may happen in the interaction session: awkward silence when no question is asked or heated discussion where question are deviated from the subjects presented. In the first case, students do not know how to express their questions, because of their limited ability. The teacher can initiate discussion by asking presenters simple questions or giving audience hints. In the second case, the teacher need to keep calm, rather than getting involved or stopping the discussion right away. It is appropriate for the teacher to bring the discussion back to the direction relevant to the subject. Teachers should control the pace of presentations to play a role of assisting in the presentations conducted by students.

\section{F. Introducing multimedia to students to have a more powerful presentation.}

In order to keep students active in presentations, in addition to accentuating the role of teachers, the way of presenting should also keep up with innovations. In recent years, multimedia is more and more widely-used in teaching. Presentations are not an exception. Students illustrate their discussion with pictures PPT or videos, making the audience more impressive. When making PPTs, students can hone their skills in searching and organizing information, in this process, they can learn things which cannot be acquired from textbooks and expand their knowledge, thus achieving the result of self-learning. Some Power Points are so excellent that they arouse audience's interests and enthusiasm immediately, which making their presentations stand out and get higher scores at the same time.

The PPTs can make presentations more impressive; however, they cannot steal the show. Some students put more efforts into making the PPT than preparing their speeches. Some speak a few words then play a long-time video. These kinds of presentations have little significance. Presentations, aiming at honing the students' skills in using language, should be student-oriented. They cannot excessively depend on multimedia.

\section{MAKING USE OF SELF AND MUTUAL EVALUATION IN}

\section{PRESENTATIONS.}

Evaluations give feedbacks about teaching and learning to students. At the end of presentations, teachers should comment briefly on the quality, thus motivating students to make progress [8].

The self and mutual evaluations give students opportunities to evaluate themselves, communicating in assessment, learning in communication and improving in learning. Students can discover their drawbacks in presenting through self-evaluation and they can enhance team spirits through comments from their group. And students can discover their classmates' merits and learn from each other. It is also an effective way to 
improve Japanese in finding flaws of their classmates' presentations. Proper comments will encourage students and help them to evaluate themselves, at the same time, telling the next presenter what they should pay attention to indirectly. If possible, the teachers can record the presentations as a tape or video which students can listen or watch afterwards. Records can help students know their strong point and weak points better.

In summary, although it is the student to conduct the presentations, teachers play a crucial role of guiding. Before allow the students to become the protagonist of class, teachers should do their job behind the scene to ensure that students can make splendid presentations.

\section{CONCLUSION}

With the updating of teaching ideas, the subjectivity of students gets increasing attention. Presentation has certain effect on improving students' subjectivity. Nevertheless, students are short of knowledge and not experienced in presenting, so they need to instruct them. What a teacher should do is more than teaching knowledge. They should guide students to autonomous learning through activities, like presentations. Therefore, teachers must be trained for more overall experience and teaching ability. They should be more experienced in connecting and integrate knowledge.

\section{REFERENCES}

[1] Wang Lizhen Analysis of Presentation [J]. Linguistics,2015(4)

[2] Ning Cuilin Exploration of Teaching pattern in Improving Business Japanese communication skills [J]. Foreign Language Teaching and Research,2015

[3] Shu Dingfang,Zhuang Zhixiang Modern Foreign Language Teaching-theoretical practice and method(revised edition)[M].Foreign Language Education Press(SFLEP),2015

[4] Xu Jinfen,Kou Jinnan Research on Interaction Pattern of Group Work in University English Teaching[J].Foreign Language Teaching,2017(2)

[5] Cui Limei Study of Application of Presentation in Advanced Japanese teaching [J]. China Education Innovation Herald,2013

[6] Lin Hong Theory and Practice of Teaching Method for Japanese Teaching[M].Higher Education Press,2015(8)

[7] Wangfengjuan. The Approaches Cultivating College Students' Learning Autonomy of English [M].Popular Literature, 2012

[8] Songquanqi,Weifang,Panxiaofu.Chinese College Students' Internal Stru cture of Autonomyin English Learning[M].Review in Psychology Research,2013 